\title{
Youth Migration in Indonesia: Decision to Move and to Choose Destination Areas
}

\author{
Meirina Ayumi Malamassam
}

Received: 10112015 / Accepted: 1102 2016 / Published online: 30062016

(C) 2016 Faculty of Geography UGM and The Indonesian Geographers Association

\begin{abstract}
Using intercensal population survey data, this paper examines migration behavior of youth in Indonesia aged 15 to 24 years old. Logistic regressions are employed to understand factors influencing youth's decision to migrate as well as their choice of destination areas. The study findings suggest that migration preferences are determined by both the individual characteristics as well as the development level in both areas of origin and destination. It is also shown that education plays an important role in youth migration in Indonesia, not only in improving individual's capacity to migrate, but also in prompting migration to big cities. In addition, youth migrants tend to move to areas with similar characteristics or similar cultural background to their areas of origin. For most of young people, migration is considered as an attempt for gaining upward social mobility, thus the prevalence of youth migration to less developed areas is low.
\end{abstract}

Keywords: Youth migration, Indonesia, Decision-making, Destination choice, Gender, Education

\begin{abstract}
Abstrak Tulisan ini mengkaji perilaku migrasi kaum muda berumur 15-24 tahun di Indonesia dengan menggunakan data survei penduduk antar sensus. Regresi logistic digunakan untuk memahami faktor-faktor yang mempengaruhi motivasi migrasi kaum muda serta daerah pilihan migrasi mereka. Kajian ini menemukan bahwa preferensi migrasi kaum muda ditentukan oleh karakteristik individu migran serta tingkat pembangunan daerah asal dan daerah tujuan migran muda. Studi ini juga menemukan bahwa pendudukan memiliki peranan penting dalam migrasi kaum muda di Indonesia, tidak hanya meningkatkan kapasitas individu untuk bermigrasi, tetapi juga mendorong terjadinya migrasi ke kota-kota besar. Selain itu, migran muda umumnya cenderung berpindah menuju daerah-daerah dengan karakteristik dan latar belakang budaya yang serupa dengan daerah asal mereka. Bagi kebanyakan kaum muda, migrasi umumnya dianggap sebagai salah satu upaya peningkatan mobilitas sosial. Oleh karena itu, prevalensi migrasi kaum muda ke daerah yang kurang maju tergolong rendah.
\end{abstract}

Kata kunci: Migrasi muda, Indonesia, Pengambilan keputusan, Pilihan tujuan, Gender, Pendidikan

\section{Introduction}

In many countries, young people dominate migration flows and they are known as the most mobile age group. In Indonesia, recent census by Indonesian's Statistics Bureau [BPS, 2011] reported that about 30 percent of migrant population in this country belonged to 15-24 age group population. The movement of the young people causes the population distribution imbalance among regions in this country, particularly between urban and rural areas.

This situation is illustrated by the opposite trend of young people growth rate in urban and rural area. From 1990 to 2000, youth population growth rate in urban areas was 3.9 per cent in contrast with 0.3 per cent in rural areas [BPS, 1990; BPS, 2000]. On one hand, the youth movement brings relief in population pressure and population density in rural areas. On the other hand, it causes higher burden of population in urban areas and higher competition in accessing urban facilities.

Meirina Ayumi Malamassam Research Center for Population - Indonesian Institute of Sciences (P2 Kependudukan -LIPI)

Email: ayumi.malamassam@gmail.com
At the individual and family level, migration is considered as an effort by young people to pursue better opportunities to improve their quality of life. Meanwhile, at the regional level, the youth migration will result in high human capital stock in destination areas at the cost of loss in high-skilled young population in the areas of origin [Faggian et al., 2007; Franklin, 2003; Winters, 2011]. This is because youth migration, especially the skilled and educated ones, can trigger the disparity of human resource development and inequality of regional development in a country.

Previous studies on migration found that the decision to migrate is highly dependent on the migrants' life aspirations as well as existing opportunities to fulfill the aspirations both in origin and destination areas. For young people, particularly, the decision to migrate can be attributed to life-cycle events related to their adolescence age, such as attending higher education, entering labor force or changing marital status [Pardede \& Muhidin, 2006]. Those events also act as major motivation for young people in determining their migration destinations [Muhidin, 2003].

Indonesia is an interesting case for studies on youth migration issues. This country is currently 
facing challenges in its human development, related to imbalanced distribution of high-skilled youth population among regions. While many studies on this topic have been conducted in other countries, such as the United States, Australia and the United Kingdom [Corcoran et al., 2010; Faggian et al., 2007; Franklin, 2003; Winters, 2011], little has been known about the youth migration in Indonesia, particularly aspects related to decision-making process of youth migration.

The flows of youth migration depend on many factors. This study examines the factors affecting youth's decision to migrate and the factors influence their choice of destination areas in Indonesia. The findings of this study will contribute to the theoretical framework on the discussion of youth migration issues in Indonesia, through the identification of determining factors of youth migration in this country. The findings, particularly, can indicate the youth migration's impact on population distribution and human development disparity in this country.

This paper begins by positioning this study within the existing youth migration literatures.

\section{Decision to migrate by young people}

A theory of migration by Lee [1966] pointed out that there are four aspects influencing the decision to migrate, namely factors associated with areas of origin, factors associated with destination area, intervening obstacles and personal factors. The theory showed that the same sets on factors associated with origin and destination areas could operate differently in different people, because different people experience different intervening obstacles and personal issues. Thus, those four aspects work together in differentiating those who decide to migrate and those who does not.

Moreover, migration is considered as a response by individual, family and community to surmount gap between their life aspirations and limited facilities in their areas of origin [Crivello, 2011; Gabriel, 2006]. Consequently, lack of educational and employment are generally suggested as the major reasons that encourage youth population to move away from their hometown [Easthope \& Gabriel, 2008; Elder et al., 1996].

Alternatively, Elder et al. [1996] suggested three determinants in youth migration, namely social context, social options and social ties. Social context refers to socioeconomic and demographic factors. Elder et al. [1996] argued that people with higher income are more likely to migrate. In regional level, however, Pollard et al. [1990] found that young people who come from areas with high income per capita are less likely to migrate. Both findings imply that level of economic development of an area influences the decision to migrate by its population. Another socioeconomic factor is migration experience. Migration experiences for young people are mostly as a part of family migration or parental migration. Easthope and Gabriel [2008] found that young people who had parents with migration experience are more likely to migrate. This is because the parents already had experienced in exposing other regions' culture and they expect their children to get the similar experience.

Demographic variables also play a role in determining young people decision to migrate. For example, a study by Magnan et al. [2007] found that the probability of young people to leave their areas of origins increases with age. In addition, the probability is higher for males than females. However, there is a higher propensity of young females to migrate in younger age than their male peers.

The second determinant that may influence migration behavior is social options. This determinant is closely related to the issue of migrant selectivity. Elder et al. [1996] found that young people with good academic achievement are more likely to leave their origin cities than those with lower educational attainment. By having better achievement than their peers, the smarter and brighter youths have greater access youths to move to other areas. Besides that, it is also found that youths with good achievement are more likely to reject the idea of living near their family and community in their young adult age. Therefore, academic achievement could play an important role on migrating decision by young people. Similarly, a study by Crivello [2011] on youth aspiration on migration in rural areas showed that good academic performance increases chances for seeking education and employment opportunities in urban areas. Therefore, the study suggested that, particularly in rural areas, better educational background enhances young people's capacity to migrate.

Another determinant affecting youth migration is social ties. Elder et al. [1996] explained that youths' attachments to their family and surroundings would influence their further residential preferences. In other words, living environment and cultural background of community of origin could influence youth's decision to migrate. Easthope and Gabriel [2008] found that when a community views those who migrate as 'the best and brightest' among their peers, many young people from the community think that migration is something they have to do in order to fulfill the community' expectations as well as to gain upward social mobility. Salzmann [2008] also showed that in a community where females are expected to prioritize family matters rather than career, highly-educated young female are more likely to migrate to pursue career opportunities.

\section{Choice of destination area by youth migrants}

The choices of destination area by the youth migrants are influenced by their future expectations and plans. Sweeney Research [2009] reported young migrants' choice on areas of destination highly depends on their expectation on education and employment opportunities at those places. Magnan et al. [2007] added migrants' familiarity with the destination areas as well as the presence of family or friends in 
the destination areas as factors affecting the choice of destination.

Furthermore, Muhidin [2003] showed that motives of migration have been an important prompt that lead to a decision of destination areas. It is found that family reason is the main motive of internal migration in most of regions in Indonesia, while educational reason is another important motive of migration, particularly from outer Java Island. Moreover, economic reason is also a major consideration on the choice of migrants' destination areas. Sweeney Research [2009] suggested that salary differences between areas of origin and destination become the main concern in deciding their workplace areas. Similarly, Magnan et al. [2007]'s study found that the decision to live in certain areas depend whether on the economic situations in those places could benefit them.

Several studies showed that the development level of the destination areas is important in attracting inmigrants. For example, an area with high human capital stock attracts more educated in-migrants [Faggian et al., 2007; Franklin, 2003; Winters, 2011]. The arrival of young educated migrants in the area results in population growth as well as human capital development in the area of destination. Similarly, based on the expectation of high economic opportunities, some young migrants prefer to move to urban or metropolitan areas [Faggian et al., 2007; Franklin, 2003].

Sweeney Research [2009] suggested that many young people, who work as professionals, believe that it is an obligation to work in big cities although they feel more convenient to live in the countryside. This is because work experiences in big cities will get higher appreciation for career development. In addition, McKenzie [2009] argued that some graduate migrants might be attracted to the lifestyle offered in big cities or metropolitan areas.

However, Corcoran et al. [2010] revealed that some young people are willing to take any job opportunities only to enter into the workforce, although they might need to move to peripheral or remote areas. Other young migrants look for cities that can give prospect of a full time and secure employment. Furthermore, young migrants with specialized skills, such as nurse or teacher, are more likely to move to peripheral or rural areas. This is because they gain more income advantage from government incentives to work at such places [Corcoran et al., 2010; McKenzie, 2009]. Pollard et al. [1990] emphasized the importance of getting the young educated migrants to move to less developed areas since the presence of well-educated inhabitants would accelerate economic development in those areas. However, this type of migration decision could be difficult for some young adult. Easthope and Gabriel [2008] expressed young migrants' opinion that migration to less developed area could represent a setback in their personal and career development.

Moreover, a study by Faggian et al. [2007] on students' repeat migration behaviour suggested that the choice of destination areas by young migrants is highly determined by their migration history. For those who have migrated before, moving distance of subsequent migration is a function of the distance on previous migration. In addition, Magnan et al. [2007] finds that young migrants with bachelor degree have higher propensity to have greater inter-regional mobility. It can be seen that migrants with high educational attainment background have more options in deciding their destination areas. This is because they already have the knowledge, the skills and the degree that can help them access various career possibilities.

\section{The Methods}

This study analyzes migration data from Indonesian Intercensal Population Survey 2005 [BPS, 2005], the latest published intercensal survey to date. Although there are other current datasets on migration in this country (such as Population Census), but SUPAS datasets present more comprehensive migration data than the others. Data from this intercensal survey contain information on individuals' residence history in county level: where they were born, where they lived five years ago, where they lived before their current residences, and their current residences. Besides that, there is also information on motives of the youths' last migration. In addition, the data also provide information on individual characteristics, such as age, sex and educational attainment.

However, there are also some constraints by using the SUPAS datasets. The population movements' information on the data are still limited because they does not cover the life time mobility of the individuals. Thus, the analysis of the relationship between motives of youth migration and their life cycle events is difficult to be studied. There is no information also on return migration flow that can determine the permanent or temporary nature of the migration. Besides that, there are limitations on the availability of demographic characteristics that may relate the individual behaviour of migration, such as birth order of the migrants.

In this study, youths are defined as those aged 15-24 years old and youth migrants are defined as youths who live in different municipalities from where they were in the past five years. The selection of this age group is based on assumption that youth migration are highly related to the occurrence of several life cycle events, namely attending higher education, involving in labor force for the first time, and getting married.

In Indonesia, the entry age for attending secondary and tertiary education is around 15 to 18 years old. Moreover, the official employment age in this country also starts from 15 years old. In addition, the median age of first marriage among ever-married aged 20-49 years old in Indonesia is 19.9 years old [BPS, BKKBN, $\mathrm{MoH}$ \& ICF International, 2012]. Total youth population sample in this data set is 202,831 , while there are 13,749 
Table 1. Logistic Regression Model: Variables of Decision to Migrate by Youth Population

\begin{tabular}{|c|c|c|}
\hline & Variable & Explanation \\
\hline Dependent & Migration status & Dummy: 0 - non migrant, 1 - migrant, \\
\hline \multicolumn{3}{|l|}{ Variable } \\
\hline Independent & Sex & Dummy: 0 - female, 1 - male \\
\hline \multirow[t]{12}{*}{ Variables } & Age & Categorical \\
\hline & & $0-15$ years old, $1-16$ years old, $2-17$ years old, \\
\hline & & $3-18$ years old, $4-19$ years old, $5-20$ years old, \\
\hline & & $6-21$ years old, $7-22$ years old, $8-23$ years old \\
\hline & & $9-24$ years old \\
\hline & Migration history & Dummy: \\
\hline & & 0 - no previous migration, 1 - had migrated before \\
\hline & Highest educational & Categorical: \\
\hline & Attainment & 0 -primary school or lower, 1 - junior high school, \\
\hline & & 2 - senior high school or above \\
\hline & Type of origin area & Categorical: \\
\hline & & 0 - town, 1 - small city, 2 - large city \\
\hline
\end{tabular}

young migrants among them or about 6 per cent of the youth population sample in this data set.

The main focus of this research is to understand the migration behavior of young people in Indonesia through the examination of young movers-stayers characteristics and the choice of destination areas of the young movers. This study applies two regression model i.e.

1. Logistic regression model is used to examine migrants and non-migrants in areas of origin and the relationship between their decision to move and their individual characteristics.

2. Multinomial regression model is used to examine the choice of destination areas of the young migrants as well as the relationship between their choices, their individual characteristics and the region characteristics.

Based on previous review of literature, Table 1 presents variables incorporated in the first model.

As argued by Elder et al. [1996], social context, social options and social ties effect on migration decision by young individuals. Variables sex, age and migration history represent factors on social context, while the variable highest educational attainment represent factors on social options. Since there is limited information on cultural background of the sample in this dataset, this study uses type of origin areas as a representation of factors on social ties. Although this classification may not reflect the cultural background among regions, but it can reflect the living environment and regional amenities shared by the populations living in same area types.

This study classifies type of origin areas based on their population density. Population density is treated as a proxy for development level of an area. It is believed that population density has a positive correlation with the level of regional development [Rappaport, 2008]. The more developed an area, the more education and employment opportunities are provided, the more urban amenities are available, it would result on attracting more population in this area and on higher population density. In this study, origin areas are classified into three types, namely town (areas with population density less than 100 persons per square kilometers), small city (areas with population density between 100 and 1,000 persons per square kilometers), and large city (areas with population density above 1,000 persons per square kilometers).

Table 2 shows the variables used in the multinomial regression model. The model distinguishes choice of destination by youth migrants uses the type of destination areas as the dependent variable. By using assumption that the development level in an area in five years would be relatively the same, the classification for destination areas use is similar with origin areas classification in the earlier model (town, small city and large city).

This multinomial regression model uses the same independent variables on the logistic model. However, there are two other variables for the latter model i.e. migration motivation and movement type. As expressed before in the literature review, migration motives have an important role in helping migrants choose their destination areas. In addition, the movement type variable is used as a proxy to identify how background similarities influence the choice of destination area by the youth migrants. This is because populations who lived in the same island commonly share similar cultural background. 
Table 2. Multinomial Regression Model: Choice of Destination Areas by Youth Migrants

\begin{tabular}{|c|c|c|}
\hline & Variable & Explanation \\
\hline $\begin{array}{l}\text { Dependent } \\
\text { Variable }\end{array}$ & Type of destination area & $\begin{array}{l}\text { Categorical: } \\
0 \text { - town, } 1 \text { - small city, } 2 \text { - large city }\end{array}$ \\
\hline Independent & Sex & Dummy: 1 - male, 0 - female \\
\hline \multirow[t]{6}{*}{ Variables } & Age & $\begin{array}{l}\text { Categorical } \\
0-15 \text { years old, } 1-16 \text { years old, } 2-17 \text { years old, } \\
3-18 \text { years old, } 4-19 \text { years old, } 5-20 \text { years old, } \\
6 \text { - } 21 \text { years old, } 7-22 \text { years old, } 8-23 \text { years old } \\
9-24 \text { years old }\end{array}$ \\
\hline & Migration history & $\begin{array}{l}\text { Dummy: } \\
0 \text { - no previous migration, } 1 \text { - had migrated before }\end{array}$ \\
\hline & $\begin{array}{l}\text { Highest educational } \\
\text { attainment }\end{array}$ & $\begin{array}{l}\text { Categorical: } \\
0 \text { - primary school or lower, } 1 \text { - junior high school, } \\
2 \text { - senior high school or above }\end{array}$ \\
\hline & Type of origin area & $\begin{array}{l}\text { Categorical: } \\
0 \text { - town, } 1 \text { - small city, } 2 \text { - large city }\end{array}$ \\
\hline & Migration motives & $\begin{array}{l}\text { Categorical: } \\
0 \text { - Family reasons, } 1 \text { - Economic reasons } \\
2 \text { - Education reasons, } 3 \text { - Other reasons }\end{array}$ \\
\hline & Movement type & $\begin{array}{l}\text { Dummy: } \\
0 \text { - intra-island, } 1 \text { - inter-island }\end{array}$ \\
\hline
\end{tabular}

\section{Result and Discussion}

This study finds only 6 per cent of recent migrants among the youth population. This proportion is higher than proportion of inter-province recent migrants of all-age population in Indonesia, which is 2.4 per cent [BPS, 2011]. It also slightly higher than all-age migration intensity among municipalities, which is 4 per cent [Bell \& Muhidin, 2009]. Hence, it could imply the concentration of incidence of migration in the young age. Table 3 compares the characteristics of youth migrants and non-migrants in Indonesia.

It is shown that there are different characteristics between migrant and non-migrant youths in Indonesia. The proportions of male and female non-migrant are quite similar, but it can be said that more female migrate than male. Moreover, most of young people in Indonesia have not had migration experience for both migrant and non-migrant groups. However, there is a much higher distribution of previous migration by those with current migrant status than the young nonmigrants.

In the education characteristics, there is an opposite trend between migrants and non- migrants. Most migrants have senior high school degree or above, in contrast with most of the non-migrants who only have primary school degree or lower.

In terms of type of origin areas, around 40 per cent of the youth migrants originate from small cities, followed by those migrating from large cities. Only around a fourth of the youth migrants are coming from areas with the lowest population density.

Furthermore, it can be seen at Figure 1 that there are different patterns of age distribution between two youth groups by their migration status in this study. While there is a nearly proportionate distribution of age among non-migrants, it is shown that there is an increasing percentage of distribution of youth migrants by age.

The results of the logistic regression model for the generation of youth migration are presented in Table 4. It is evident that all variables included in the model have significant effects on the youth migration status. It is also shown that there is a positive correlation between education back-ground and propensity to migrate. It can be said that education significantly improves individual's capability of migrating. However, this situation also leads to human capital loss in areas of origin.

Moreover, young females are more likely to migrate than the male counterparts. This finding is quite different from the trend of recent migration of all-age in Indonesia where male's migration is higher than female's [BPS, 2011].

However, by taking into account the interaction term between sex and education background, it is found that the odds to migrate between male and female only 


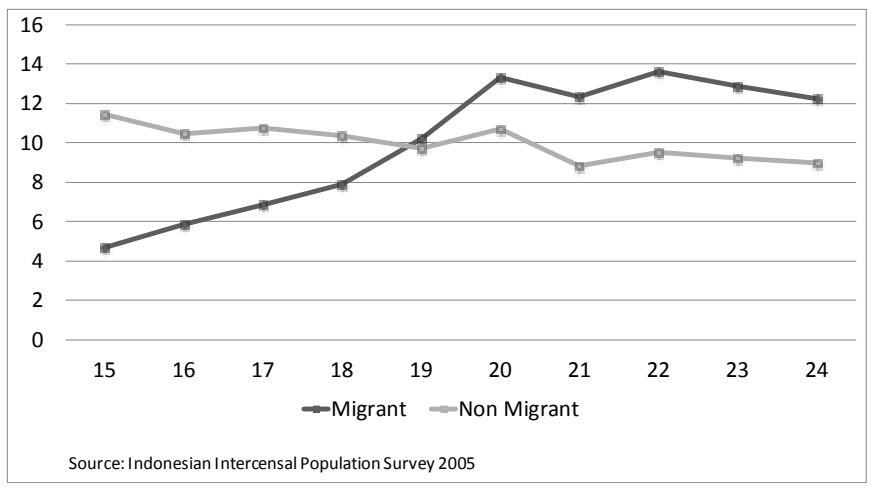

Figure 1. Age distribution by migration status.

Table 3. Summary Statistics of Individual \& Regional Characteristics of Youth Indonesian by Their Migration Status

\begin{tabular}{llrr}
\hline Variables & & $\begin{array}{c}\text { Migrant } \\
(\%)\end{array}$ & $\begin{array}{c}\text { Non } \\
\text { Migrant } \\
(\%)\end{array}$ \\
\hline Sex & - Male & 43 & 51 \\
& - Female & 57 & 49 \\
& Total \% & 100 & 100 \\
Migration & - No previous migra- & 66 & 87 \\
history & tion & & \\
& - Had migrated before & 34 & 13 \\
& Total \% & 100 & 100 \\
Highest & - $\leq$ Primary school & 24 & 40 \\
educational & - Junior high school & 31 & 35 \\
attainment & - $\geq$ Senior high school & 45 & 25 \\
& Total \% & 100 & 100 \\
Type of & - Town & 24 & 39 \\
origin areas & - Small city & 41 & 36 \\
& - Large city & 35 & 25 \\
& Total \% & 100 & 100 \\
& & $\mathrm{~N}=$ & $\mathrm{N}=$ \\
& & 13,749 & 189,082
\end{tabular}

Source: Indonesian Intercensal Population Survey, 2005

differ significantly at the lowest educational degree. There is a higher probability for young female with educational qualification of primary school or lower to migrate than the male counterparts, while there are no significant differences in propensity to migrate between male and female who has high school qualification or above. This situation could be explained by the findings of BPS [2011] that reported that there is an increasing number of young female from rural areas who migrate to work in domestic sectors as maids in urban areas.

According to Bell and Muhidin [2009], age is the most consistent explanatory variable in predicting migration probability within an area. This study shows that those aged 21-22 years old have the highest odds to migrate. The results are in line with studies by Bell and Muhidin [2009] which argued that the peak age of migration in most Asian countries is around their early twenties. The probabilities of ten categories of age in this study is similar with the pattern of migration of allage in Indonesia [BPS, 2011].

Migration experience plays a major role in determining migration decision by the youth. Those with previous migration experience are three times more likely to migrate than those without. Magnan et al. [2007] suggested that for young people, migration is viewed as a journey, not as an exodus. Therefore, once young people migrate, there is a high propensity for them to have subsequent migrations.

Although several studies on migration in Indonesia report the high incidence of rural-to- urban migration [Tirtosudarmo, 2009; Van Lottum \& Marks, 2012], the finding of this study shows that those originating from towns have the least probability to migrate. In contrast, youth originating from small and big cities are nearly two times more mobile than those from towns. This situation can be explained with the understanding that migration is a practice that requires access of information, network availability and cost to move.

On one hand, despite their migration intentions, those who live in towns have limited access to some of the migration requirements and this result on low outmigration from this region's type. On the other hand, although small and large cities provide urban amenities, employment opportunities and higher educational facilities, young people who stay in those areas has high propensity to migrate since they are more likely to have access to all the migration requirements and this increases their capabilities to move to other areas. Presumably, for them, migration is not a decision made as a strategy to survive or to fulfil their basic needs. The migrant status, however, can help youth migrants gain upward social mobility, especially in their communities of origin [Easthope \& Gabriel, 2008; Morrison \& Clark, 2011].

Further analysis is conducted in order to examine the choice of destination by young migrants in Indonesia. Table 5 shows the descriptive summary 
of youth migrants' characteristics by the type of their destination areas.

Table 4. Results of Logistic Regression Analysis of Youth's Migration Status

\begin{tabular}{|c|c|c|c|}
\hline Variables & $\mathrm{B}$ & SE & $\operatorname{Exp}(B)$ \\
\hline \multicolumn{4}{|l|}{ Sex } \\
\hline - Male & -0.276 & 0.018 & 0.759 \\
\hline - Female & 0 & 0 & 1 \\
\hline \multicolumn{4}{|l|}{ Age } \\
\hline - 24 years old & 0.706 & 0.05 & 2.026 \\
\hline-23 years old & 0.747 & 0.049 & 2.11 \\
\hline - 22 years old & 0.792 & 0.049 & 2.208 \\
\hline-21 years old & 0.782 & 0.05 & 2.185 \\
\hline - 20 years old & 0.723 & 0.049 & 2.061 \\
\hline - 19 years old & 0.579 & 0.051 & 1.784 \\
\hline - 18 years old & 0.344 & 0.052 & 1.41 \\
\hline - 17 years old & 0.244 & 0.053 & 1.277 \\
\hline - 16 years old & 0.185 & 0.055 & 1.203 \\
\hline - 15 years old & 0 & 0 & 1 \\
\hline \multicolumn{4}{|c|}{ Highest educational attainment } \\
\hline - $\geq$ Senior high school & 0.674 & 0.025 & 1.962 \\
\hline - Junior high school & 0.31 & 0.025 & 1.364 \\
\hline - $\leq$ Elementary school & 0 & 0 & 1 \\
\hline \multicolumn{4}{|l|}{ Migration history } \\
\hline - Had migrated before & 1.149 & 0.02 & 3.157 \\
\hline - No previous migration & 0 & 0 & 1 \\
\hline \multicolumn{4}{|l|}{ Type of origin area } \\
\hline - Large city & 0.63 & 0.024 & 1.877 \\
\hline - Small city & 0.683 & 0.023 & 1.98 \\
\hline - Town & 0 & 0 & 1 \\
\hline Constant & -4.09 & 0.045 & \\
\hline $\mathrm{N}$ & 202,831 & & \\
\hline
\end{tabular}

It can be seen that large cities, in general, are the main destination, followed by small cities and towns. This implies that the level of development of an area has become a major factor influencing the choice of destination. Large cities become the major preference of destination since they offer employment opportunities, educational facilities and urban lifestyles [Fahchamps \& Shilpi, 2013; McKenzie, 2009]. These features attract lots of young population to be in-migrant in these areas. In addition, Franklin [2003] argued that areas with high number of educated people have high capability to attract more skilled in-migrants. Therefore, the addition of the in-migrants would result in higher population density in those areas.

However, there are differences in the distribution pattern of destination choice by particular individual and regional characteristics. For example, while the proportions of male and female migrating to small cities are the same, the proportions differ slightly for migration to large cities. It is also shown that more males migrate to towns, while more females migrate to large cities. Major preference to migrate to large cities is also shown from the different levels of educational background. In addition, there is only slight different percentage between migrate to towns and large cities for those with lowest educational background.

The percentage distribution of destination choice by types of origin areas shows that almost a half of migrants from town choose to migrate to the same area type, while the majority of migrants from small and large city choose to migrate to large city. Moreover, the majority of youth migrations are intra-island movements, with nearly a half of intra-island movements ends at large city, while inter-island movements are mostly destined to town. As argued by Argent and Walmsley [2008], the choices of destination by the youth migrants are more likely within the same region as their origin areas. It can be said that they put cultural similarity and distances as major consideration on choosing destination areas.

Large city also becomes choice of destination by the majority of migrants who move for education and economic reasons. However, the proportion of migration for family reason is distributed quite evenly to the three types of destination areas. Table 6 presents results of multinomial logistic regression estimating distribution of migration to three different types of destination areas.

It is evident that most of the variables are statistically significant for estimating the choice of destination type. However, age is insignificant factor in explaining choice of destination by youth migrants in Indonesia. Another insignificant explanatory variable is educational attainment for those two lowest levels of education, because there are no significant differences between probabilities of migration to towns and small cities. In addition, migration experience is also insignificant in estimating difference of migration probabilities to towns and small cities. Figure 2 shows predicted percentage of choice of destination by the migrants' origin and the movement types.

It can be seen that large city becomes the main destination of youth migration in Indonesia for those originating from small and large cities. However, for those originating from town, they have low probability to move to small and large cities. This illustrates young people are more likely to migrate to areas with similar characteristics with their areas of origin. According to Fafchamps and Shilpi [2013], migrants tend to move to nearby area that has higher population which shared similar culture with their origin areas. In addition, Magnan et al. [2007] suggest that migrants' familiarity with the destination areas affects their choice of destination. This can help them to easily adapt to culture and life style of destination areas, particularly 
Table 5. Summary Statistics of Individual and Regional Characteristics of Youth Migrants by Their Type of Destination Areas

\begin{tabular}{|c|c|c|c|c|c|c|}
\hline \multirow{2}{*}{ Variables } & & \multicolumn{3}{|c|}{ Type of destination areas (\%) } & \multicolumn{2}{|c|}{ Total \% (N) } \\
\hline & & \multirow{2}{*}{$\begin{array}{r}\text { Town } \\
30\end{array}$} & \multirow{2}{*}{$\begin{array}{r}\text { Small city } \\
29\end{array}$} & \multirow{2}{*}{$\begin{array}{r}\text { Large city } \\
41\end{array}$} & \multirow[b]{2}{*}{100} & \multirow[b]{2}{*}{$(5,958)$} \\
\hline Sex & - Male & & & & & \\
\hline \multirow{11}{*}{ Age } & - Female & 25 & 29 & 46 & 100 & $(7,791)$ \\
\hline & - 15 years old & 34 & 27 & 39 & 100 & $(641)$ \\
\hline & - 16 years old & 28 & 30 & 42 & 100 & $(807)$ \\
\hline & - 17 years old & 28 & 29 & 43 & 100 & (945) \\
\hline & - 18 years old & 31 & 27 & 42 & 100 & $(1,087)$ \\
\hline & - 19 years old & 24 & 29 & 47 & 100 & $(1,407)$ \\
\hline & - 20 years old & 26 & 27 & 47 & 100 & $(1,834)$ \\
\hline & - 21 years old & 25 & 29 & 47 & 100 & $(1,695)$ \\
\hline & - 22 years old & 25 & 29 & 46 & 100 & $(1,873)$ \\
\hline & - 23 years old & 28 & 30 & 42 & 100 & $(1,775)$ \\
\hline & - 24 years old & 29 & 29 & 41 & 100 & $(1,685)$ \\
\hline \multirow{3}{*}{$\begin{array}{l}\text { Highest educational } \\
\text { attainment }\end{array}$} & $-\leq$ Primary school & 34 & 29 & 37 & 100 & $(3,318)$ \\
\hline & - Junior high school & 29 & 29 & 42 & 100 & $(4,244)$ \\
\hline & - $\geq$ Senior high school & 22 & 29 & 50 & 100 & $(6,187)$ \\
\hline \multirow[t]{3}{*}{ Type of origin areas } & - Town & 45 & 31 & 24 & 100 & $(3,230)$ \\
\hline & - Small city & 24 & 24 & 52 & 100 & $(5,644)$ \\
\hline & - Large city & 20 & 32 & 48 & 100 & $(4,875)$ \\
\hline \multirow[t]{2}{*}{ Migration history } & - No previous migration & 25 & 25 & 50 & 100 & $(9,108)$ \\
\hline & - Had migrated before & 31 & 36 & 32 & 100 & $(4,641)$ \\
\hline \multirow[t]{3}{*}{ Migration motives } & - Family reasons & 36 & 30 & 34 & 100 & $(5,237)$ \\
\hline & - Economic reasons & 22 & 29 & 57 & 100 & $(4,851)$ \\
\hline & - Education reasons & 17 & 26 & 57 & 100 & $(3,072)$ \\
\hline \multirow[t]{2}{*}{ Movement type } & - Intra - island & 25 & 28 & 48 & 100 & $(10,977)$ \\
\hline & - Inter - island & 38 & 33 & 30 & 100 & $(2,722)$ \\
\hline
\end{tabular}

Source: Indonesian Intercensal Population Survey 2005

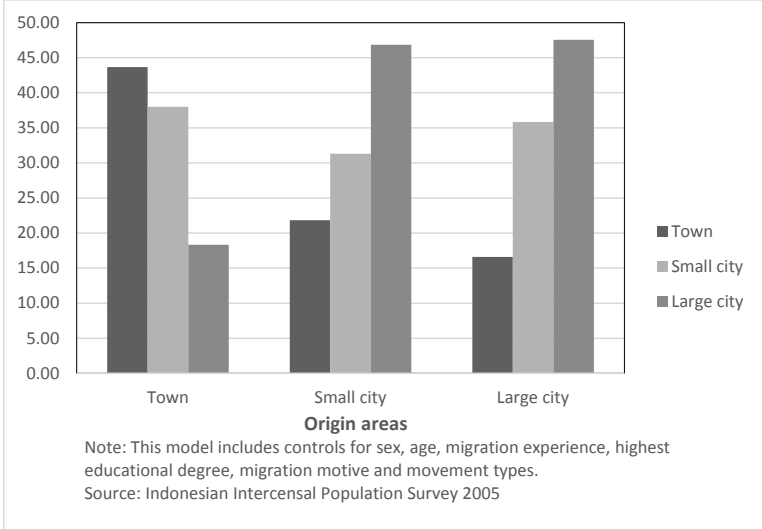

Figure 2. Predicted probability of youth migrants' destination by type of origin areas.

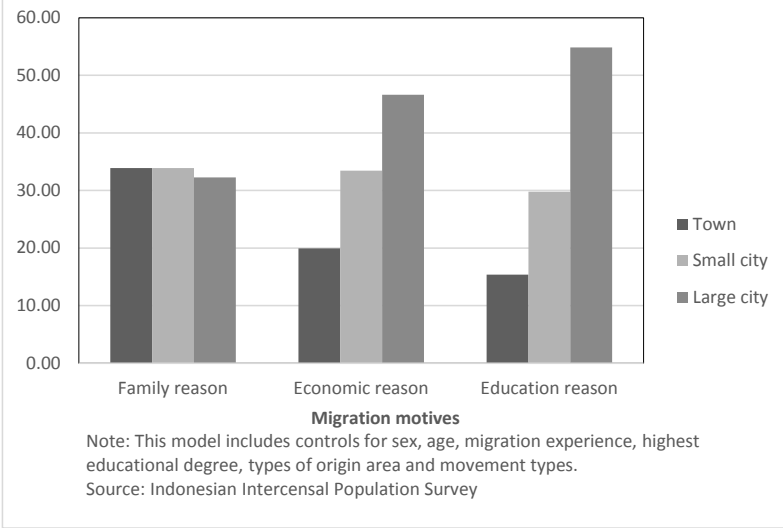

Figure 3. Predicted probability of youth migrants' destination type by migration motives. 
Table 6. Results of Multinomial Logistic Estimates of Youth Migrants' Choice of Destination Areas

\begin{tabular}{|c|c|c|c|c|c|c|}
\hline \multirow[t]{3}{*}{ Independent Variables } & \multicolumn{6}{|c|}{ Dependent Variable : Type of destination area } \\
\hline & \multicolumn{3}{|c|}{ Small city } & \multicolumn{3}{|c|}{ Large city } \\
\hline & Coef. & SE & RRR & Coef. & SE & RRR \\
\hline \multicolumn{7}{|l|}{ Sex } \\
\hline - Male & -0.267 & 0.048 & 0.766 & -0.368 & 0.047 & 0.692 \\
\hline - Female & 0 & 0 & 1 & 0 & 0 & 1 \\
\hline \multicolumn{7}{|l|}{ Age } \\
\hline - 24 years old & $-0.125^{\star}$ & 0.129 & 0.882 & $-0.167^{\star}$ & 0.127 & 0.864 \\
\hline - 23 years old & $-0.043^{*}$ & 0.127 & 0.958 & $-0.131^{*}$ & 0.126 & 0.877 \\
\hline - 22 years old & $0.074^{*}$ & 0.127 & 1.077 & $0.074^{*}$ & 0.126 & 1.078 \\
\hline - 21 years old & $0.028^{*}$ & 0.129 & 1.029 & $0.002^{*}$ & 0.127 & 1.002 \\
\hline - 20 years old & $-0.025^{*}$ & 0.127 & 0.975 & $0.021^{*}$ & 0.125 & 1.022 \\
\hline - 19 years old & $0.148^{*}$ & 0.132 & 1.16 & $0.132^{*}$ & 0.13 & 1.141 \\
\hline - 18 years old & $-0.102^{*}$ & 0.134 & 0.903 & $-0.103^{*}$ & 0.132 & 0.902 \\
\hline - 17 years old & $0.113^{*}$ & 0.138 & 1.12 & $-0.004^{*}$ & 0.136 & 0.995 \\
\hline - 16 years old & $0.192^{\star}$ & 0.141 & 1.212 & $0.110^{*}$ & 0.141 & 1.117 \\
\hline - 15 years old & 0 & 0 & 1 & 0 & 0 & 1 \\
\hline \multicolumn{7}{|l|}{ Educational attainment } \\
\hline - $\geq$ Senior high school & 0.237 & 0.642 & 1.267 & 0.441 & 0.064 & 1.555 \\
\hline - Junior high school & $0.049^{*}$ & 0.063 & 1.05 & 0.168 & 0.062 & 1.183 \\
\hline$-\leq$ Elementary school & 0 & 0 & 1 & 0 & 0 & 1 \\
\hline \multicolumn{7}{|l|}{ Migration experience } \\
\hline - Had migrated before & $0.092^{*}$ & 0.049 & 1.097 & -0.764 & 0.051 & 0.465 \\
\hline - No previous migration & 0 & 0 & 1 & 0 & 0 & 1 \\
\hline \multicolumn{7}{|l|}{ Type of origin area } \\
\hline - Large city & 0.909 & 0.061 & 2.481 & 1.92 & 0.065 & 6.82 \\
\hline - Small city & 0.049 & 0.058 & 1.646 & 1.629 & 0.061 & 5.1 \\
\hline - Town & 0 & 0 & 1 & 0 & 0 & 1 \\
\hline \multicolumn{7}{|l|}{ Migration motives } \\
\hline - Education & 0.662 & 0.071 & 1.092 & 1.322 & 0.068 & 3.752 \\
\hline - Economic & 0.518 & 0.056 & 1.94 & 0.9 & 0.055 & 2.46 \\
\hline - Family & 0 & 0 & 1.679 & 0 & 0 & 1 \\
\hline \multicolumn{7}{|l|}{ Migration type } \\
\hline - Inter-island & -0.34 & 0.055 & 0.712 & -1.208 & 0.058 & 0.299 \\
\hline - Intra-island & 0 & 0 & 1 & 0 & 0 & \\
\hline Constant & -0.657 & 0.115 & & -1.01 & 0.116 & \\
\hline $\mathrm{N}=13,749$ & & & & & & \\
\hline
\end{tabular}

Note: Base category is migration to towns; ${ }^{\star}=$ significant at $\mathrm{p}<0.10$

Source: Indonesian Intercensal Population Survey 2005

for majority of youth migrants who are first time migrants. Figure 3 shows predicted percentage of choice of destination by migration motives.

There is a proportionate distribution of probabilities to move to the three types of destination areas for those migrating for family reason. However, the majority of migrants with educational motive are predicted would move to large cities (65 per cent), while it is only 10 per cent of migrants for this purpose who predicted prefer to town. This situation illustrates a huge gap of higher education facilities among regions in Indonesia. This also shows high propensity of human capital flow from less to more developed regions. Hence, migration for education purposes could also represent the deceleration of economic development in the areas of origin since they loss their skilled and educated youth 
people [Pollard et al., 1990].

Economic motive is also a major reason to move to large cities. However, the probability to move to those areas of this motive is slightly lower (55 per cent) than probability of education motive. Similarly, this also illustrates disparity on employment opportunities between the less and more developed regions in Indonesia. However, the higher probability to move to towns and small cities could indicate less concentration of economic opportunities in areas with the densest population.

Since Van Lottum and Marks [2013] suggested areas that offer high employment opportunities are not always become the major preference of internal labour migrants, this situation also illustrates the willingness of some youth migrants to take job opportunities without taking into account the level of development of the destination areas, especially because the opportunities could be their first attempt entering workforce. Hence, youth may not always choose to work in big cities that offered higher income and urban lifestyle, but they might choose to work in small cities and town through the consideration tangible opportunities for their economic improvement in those areas.

\section{Conclusion}

This paper aimed to understand migration preferences by young people in Indonesia. Although youth migrants are only a small part of youth population in Indonesia, it is still important to understand the trend and pattern of their movement. This is because youth migration not only reflects the level of development area of origin and destination areas, but also illustrates brain and skill flows among regions in the country.

The findings of this study demonstrate that the likelihood to migrate and to choose particular areas of destination by the young people is determined by combination of individual demographic characteristics as well as development of origin dan destination areas. By controlling other variables, probability to migrate by young people in Indonesia is higher for female, more educated individuals, youths originating from small and large cities, youths who had migrated beforehand, and those at their early twenties. However, an interaction terms between sex and educational background shows that the higher probability of migrating for female is only occurred for those with primary school qualification or lower.

Furthermore, the low propensity to migrate of youth originating from towns, despite the limited education and employment opportunities available in these areas, is assumed related to their constraints on accessing information about the destination areas, building network with other migrants or natives in destination areas, or having sufficient financial resources to pay the migration costs.

The study also shows that large city has become main destination for youth migration, particularly for economic and education reasons. This situation implies inequality of educational facilities and economic opportunities among regions. Consequently, it would impact on youth urbanization as well as disparity of human capital development between the least and the most developed regions in this country. As youths viewed migration as a means for gaining upward social mobility, migration to the less developed areas, which provide limited urban amenities, is considered as an impediment for their future plans and expectations. This situation is reflected on a low prevalence of youth migration to towns and small cities.

Moreover, the higher probability for those migrating with economic motive to move to towns and small cities than migrants with educational motive indicates a less concentrated economic opportunities, compared with the distribution of higher education facilities among regions in Indonesia. This study also found the higher propensity of youth to move to areas with similar characteristics to their areas of origin and to areas within the same island. This illustrates the importance of migrants' familiarity with the environment of destination areas in determining their choice of destination areas.

Findings of this study are expected to contribute to the enrichment of the knowledge on internal migration flows, particularly youth migration flows in Indonesia. However, the limitation of the data may hinder the research to have a comprehensive analysis on social and cultural aspects of youth migration in Indonesia. Those aspects are have not been widely discussed in this study. Therefore, future studies on the youth migration with more extensive datasets, which include more social and culture variables, are encouraged.

Besides that, given the major role of education shown in this study, not only its role to enhance youth's capacity to migrate, but also its effect on the decision of the youth migrants to move to large city, future work on the migration for educational purposes in Indonesia should be encouraged. In particular, future researches are also needed to be conducted on the subsequent migration behavior of those who migrate for education motive and its effect on the human capital development among regions in Indonesia.

\section{References}

Argent, N.M. \& Walmsley, D.J. (2008). Rural youth migration trends in Australia: an overview of recent trends and two inland case studies. Geographical Research. 46(2), 139-152.

Bell, M. \& Muhidin, S. (2009). Cross-national comparisons of internal migration (UNDP Human Development Research Paper Volume 30). New York: Human Development Report Office (HDRO), United Nations Development Programme (UNDP).

Biro Pusat Statistik (BPS) (1990). Penduduk Indonesia: Hasil sensus penduduk 1990. Jakarta: BPS. 
Biro Pusat Statistik (BPS) (2000). Penduduk Indonesia: Hasil sensus penduduk 2000. Jakarta: BPS.

Biro Pusat Statistik (BPS) (2005). Survei Penduduk Antar Sensus 2005 (SUPAS 2005) [Data set]. Jakarta: BPS.

Biro Pusat Statistik (BPS) (2011). Migrasi Internal Penduduk Indonesia. Jakarta: BPS.

Corcoran, J., Faggian, A., \& McCann, P. (2010). Human capital in remote and rural Australia: The role of graduate migration. Growth and Change, 41, 192220.

Crivello, G. (2011). Becoming somebody: Youth transitions through education and migration in Peru. Journal of Youth Studies. 14(4), 395-411.

Elder, G.H.Jr., King, V., \& Conger, R.D. (1996). Attachment to place and migration prospects: A developmental perspectives. Journal of Research and Adolescence. 6(4), 397-425.

Easthope, H., \& Gabriel, M. (2008). Turbulent lives: Exploring the cultural meaning of regional youth migration. Geographical Research, 46(2), 172-182.

Fafchamps, M., \& Shilpi, F. (2013). Determinants of the choice of migration destination. Oxford Bulletin of Economics and Statistics. 75(3), 388-409.

Faggian, A., McCann, P., \& Sheppard, S. (2007). Human capital, higher education and graduate migration: an analysis of Scottish and Welsh students. Urban Studies. 44(13), 2511-2528.

Franklin, R.S. (2003). Migration of the young, single and college educated: 1995 to 2000 (Census 2000 Special Reports, CENSR-12). Washington DC: Government Printing Office.

Gabriel, M. (2006). Youth migration and social advancement: How young people manage emerging differences between themselves and their hometown. Journal of Youth Studies. 9(1), 33-46.

Everett S. Lee (1966). A Theory of Migration. Demography.3(1), 47-57.

Magnan, M.O., Gauthier, M., \& Cote, S. (2007). Youth migration in Quebec: Survey results obtained from Anglophones 20 to 34 years of age. Montreal: Institut national de la recherché scientifique Urbanisation.

McKenzie, F. (2009). Regional youth migration and the influence of tertiary institutions. Melbourne: Department of Planning and Community Development. The Victorian Government.

Morrison, P.S., \& Clark, W.A.V. (2011). Internal migration and employment: macro flows and micro motives. Environment and Planning. 43(8), 1948-1964.

Muhidin, S. (2003). Migrated household in Indonesia: An exploration of the Intercensal survey data (Asian MetaCentre Research Paper Series No. 8). Singapore: National University of Singapore.

Pardede, E. \& Muhidin, S. (2006). Life course stages and migration behaviour of Indonesian population: Evidence from the IFLS data. Paper presented at the 2006 Annual Meeting of the Population Association of American. Los Angeles, CA.

Pollard, K., O’Hare, W.P., \& Berg, R. (1990). Selective migration of rural high school seniors in the 1980s. Washington DC: Population Reference Bureau.

Rappaport, J. (2008). Consumption amenities and city population density. Regional Science and Urban Economics.38(6), 533-552.

Salzmann, S. (2008). Migration for education: Studying abroad and return to the home country, the example Kyrgz university graduates (Unpublished Master Thesis). Department of Geography University of Zurich, Zurich.

Statistics Indonesia (Badan Pusat Statistik - BPS), National Population and Family Planning Board (BKKBN), Ministry of Health (Kemenkes), and ICF International. (2013). Indonesia Demographic and Health Survey 2012. Jakarta: BPS, BKKBN, Kemenkes and ICF International.

Sweeney Research. (2009). Youth migration study report: Part 2. Melbourne: Department of Planning and Community Development. The Victorian Government.

Tirtosudarmo, R. (2009). Mobility and human development in Indonesia (UNDP Human Development Research Paper Volume 19). New York: Human Development Report Office (HDRO). United Nations Development Programme (UNDP).

Van Lottum, J., \& Marks, D. (2012). The determinants of internal migration in a developing country: Quantitative evidence for Indonesia, 1930-2000. Applied Economics. 44(34), 4485-4494.

Winters, J.V. (2011). Human capital and population growth in nonmetropolitan U.S. counties: the importance of college student migration. Economic Development Quarterly. 25(4), 353-365. 